\title{
IDENTIFYING MEDIUM-SIZED AGRICULTURAL ENTERPRISES WITH THE GREATEST POTENTIAL FOR INNOVATION DEVELOPMENT
}

\begin{abstract}
Sonja Đuričin ${ }^{1}$, Isidora Beraha ${ }^{2}$
*Corresponding authorE-mail: sonja.djuricin@ien.bg.ac.rs

A R T I C L E I N F O
Review Article
Received: 09 April 2020
Accepted: 26 November 2020
doi:10.5937/ekoPolj2101213D
UDC 631.164.6:330.341.1

Keywords:

medium-sized agricultural enterprises, financial strength, bankruptcy, innovation

JEL: Q12, Q16

A B S T R A C T

The aim of the research is to identify medium-sized agricultural enterprises with the greatest potential for innovation development. The subject of the research is the key financial performance of the observed enterprises in 2017. Data were obtained from official financial statements publicly available on the website of the Serbian Business Registers Agency (SBRA). The aim of the research was realized by applying financial analysis methods and the Altman Z-score model. The purpose of the research is to improve the efficiency of limited funds for financing innovative activities in the agricultural sector. The research results are data on enterprises with negligible probability of bankruptcy and which thus have the greatest potential for innovation development.
\end{abstract}

(C) 2021 EA. All rights reserved.

\section{Introduction}

Compared to the EU average, the Republic of Serbia has recorded a significant deviation in R\&D investment (Đuričin, 2018). The average investment in R\&D is $0.84 \%$ of GDP in the Republic of Serbia (SORS, 2017), and $2.03 \%$ of GDP in the European Union (Eurostat, 2018). Furthermore, the Republic of Serbia is characterized by a lack of efficiency of budget funds intended for financing innovation activities (Đuričin, 2018). Pursuant to the Law on Innovation Activity ("Official Gazette of RS"., No. 110/05, 18/10 and 55/13), the beneficiaries of the state incentive measures and budgetary funds for the development of the innovation activity can be only the subjects entered into the Innovation Activity Registry (the Registry). In the period 2007-2017, a large number of projects were co-financed by the budget funds, which were led by innovation organizations that were deleted from the Registry, i.e. which no longer exist

1 Sonja Đuričin, Ph.D., Research Associate, Institute of Economic Sciences, 12 Zmaj Jovina Street, Belgrade, Phone: +381 638438 896, E-mail: sonja.djuricin@ien.bg.ac.rs, ORCID ID (https://orcid.org/0000-0002-8181-7332)

2 Isidora Beraha, Ph.D., Research Associate, Institute of Economic Sciences, 12 Zmaj Jovina Street, Belgrade, Phone: +381 641455 955, E-mail: isidora.beraha@ien.bg.ac.rs, ORCID ID (https://orcid.org/0000-0002-0819-4909)

http://ea.bg.ac.rs 
(Đuričin, 2018). Out of 125 organizations registered for innovation, 55 were deleted from the Registry (MESTD, LRIO, 2018). According to financial statements, publicly available on the Serbian Business Registers Agency's website, the structure of active innovation organizations comprises $52 \%$ of micro enterprises, $45 \%$ of small- and $3 \%$ of medium-sized enterprises. On the other hand, a small number of projects in the field of agriculture were financed from the funds of the Innovation Fund.

The aim of the research was determined by inefficient placement of budgetary funds and their presence in small percentage in medium-sized enterprises. The aim of the research is to identify medium-sized agricultural enterprises with the greatest potential for innovation development. This approach to research resulted from the large number of closed innovation organizations that had funded their projects from budgetary funds. Although they are not entered in the Registry and have no right to use budgetary funds to finance their innovative activities, it is of utmost importance to determine whether medium-sized agricultural enterprises have the potential to develop innovation at all. Medium-sized enterprises, as bearers of national economic growth, fulfil all the conditions to become bearers of innovation activities. The question is whether they have the financial potential to develop innovation, i.e. which of them are most eligible for innovative activities in terms of financial failure assessment.

In the total number of companies, medium-sized enterprises account for $2 \%$ and generate $16 \%$ of employment, $17 \%$ of revenues, $16 \%$ of expenditures and $16 \%$ of the total net profit of all companies in the country (Đuričin, Beraha, 2018a). In the agricultural sector, they account for $7 \%$ of the total number of medium-sized enterprises (Ibidem.). The research aims to identify in the total number of medium-sized agricultural enterprises those which have the greatest potential for innovation development. The purpose of the research is to improve the efficiency of placement of limited funds for financing innovative activities in the agricultural sector.

The subject of the research is the key financial performance of medium-sized agricultural enterprises in 2017. Data were obtained from official financial statements publicly available on the website of the Serbian Business Registers Agency (SBRA). The aim of the research was realized by applying the methods of financial analysis, Altman Z-score model, as well as the standard methods of data acquisition and analysis and synthesis methods.

\section{Methods}

The application of standard methods of data collection and analysis determined the number of projects in the field of agriculture, co-financed by the Ministry of Education, Science and Technological Development in the period 2007-2017. Furthermore, the organizations that led those projects were identified. Among them, there is a percentage of organizations who no longer do business (status: "deleted from the Registry"). The same method was used for identifying project leaders in the field of agriculture, where project implementation was co-financed with the funds of the Innovation Fund. The 
leaders of these projects were also analysed from the aspect: "active" / "deleted from the Registry". Three programs were specifically observed within the Innovation Fund: Mini Grants Program, Collaborative Grant Scheme Program, and Matching Grants Program.

Based on the data from the financial statements, the probability of bankruptcy of medium-sized agricultural enterprises was assessed using the Altman $\mathrm{Z}$ score method (Altman, 1968; Đuričin, Bodroža, 2013; Đuričin, 2018). Assessment of bankruptcy probability of medium-sized agricultural enterprises enables identification of business entities operating in the white zone of business and as such having the greatest potential for innovation development.

The most used method in predicting the bankruptcy of the company was created as a result of Altman and other authors in the period from 1968 to 2002 (Rajin, Milenković \& Radojević, 2016). Altman Z score method was used to assess the financial failure of medium-sized agricultural enterprises (Đuričin, 2018). In order to assess the probability of bankruptcy as accurately as possible, the data from the company's official financial statements for 2017 were used. Data for only one business year was used to reduce the risk of inaccurate assessment of bankruptcy. Bankruptcy assessments were made based on the Altman Z score model aimed at unlisted companies (Altman, 2000):

$Z=0.717 x_{1}+0.847 x_{2}+3.107 x_{3}+0.420 x_{4}+0.998 x_{5}$

Each indicator is weighted by a specific coefficient. The coefficients are calculated as follows:

- $\mathrm{X}_{1}-$ Working capital / Total Assets

- $\mathrm{X}_{2}-$ Retained Earnings / Total Assets

- $\mathrm{X}_{3}-$ Earnings before interest and taxes / Total Assets; EBIT / Total Assets

- $\mathrm{X}_{4}-$ Book value of equity / Book Value of Total Debt

- $\mathrm{X}_{5}-$ Sales / Total Assets.

According to the zone of discrimination, after calculating the value of $\mathrm{Z}$ score, the probability of bankruptcy was assessed. The discrimination zone in the model used is as follows:

- Black zone $\mathrm{Z}<1.23$,

- Grey zone $1.23<\mathrm{Z}>2.90$, and

- White zone $\mathrm{Z}>2.90$.

The method of financial analysis was then applied in the research. The subject of financial analysis is the performance of medium-sized agricultural enterprises operating in the white zone. Applying the quantitative and qualitative analysis of each individual financial indicator in the Altman Z score model provided data on liquidity, indebtedness, productivity, reproductive capacity and ability to sell products and services (Đuričin et al., 2018). 
The knowledge of the subject of the research was obtained using synthesis methods. The description of the acquired knowledge drew conclusions about medium-sized agricultural enterprises with the greatest potential for innovation development.

\section{Results and Discussion}

In the period 2007-2017, the MESTD financed a total of 398 projects, of which 37 were projects in the field of agriculture (9\%). Projects in the field of agriculture were run by 20 innovation organizations. This means that one innovation organization ran two or more projects. Out of a total of 20 innovation organizations whose projects were funded by the MESTD, 4 were deleted from the Registry. These four organizations were in charge of five projects in the field of agriculture.

With regard to the Innovation Fund, projects analysed were in the field of food industry and agriculture and were co-financed under 3 programs: Mini Grants Program, Collaborative Grant Scheme Program, and Matching Grants Program.

A total of 61 projects were co-financed under the 2012-2018 Mini Grants Program. Out of the total number of co-financed projects, only 5 projects were from the food industry and agriculture. Projects in the field of food industry and agriculture were cofinanced by $8 \%$ of the total amount of the Fund used for co-financing projects under the Mini Grants Program. Five projects in the field of food industry and agriculture were implemented by four companies. One company appeared as the Leader of two projects. All four companies that ran these projects belong to the group of micro enterprises and still operate as active business entities.

In the period 2017-2019, a total of 14 projects were co-financed under the Collaborative Grant Scheme Program, 4 of which were in the field of food and agriculture. All four projects were implemented by different institutions, i.e. two institutes and two faculties in the field of technological sciences. The institutes and faculties that ran these projects still operate as active legal entities. Projects in the field of food and agriculture were cofinanced by $29 \%$ of the total amount used to co-finance projects under the Collaborative Grant Scheme Program.

In the period 2013-2018, a total of 17 projects were implemented under the Matching Grants Program. Out of the total number of co-financed projects, one was in the field of food industry and agriculture. Only $5 \%$ of the funds used to co-finance projects under this Program were spent on projects in the food and agriculture sectors. The project was run by a micro enterprise that is still active.

When it comes to the potential for innovation development within medium-sized agricultural enterprises, the following results were obtained using the Altman Z score method:

- $53.97 \%$ in black zone,

- $42.86 \%$ in grey zone, and

$-3.17 \%$ in white zone. 
Figure 1. Results of Altman Z score model in medium-sized agricultural enterprises, 2017 - in \% -

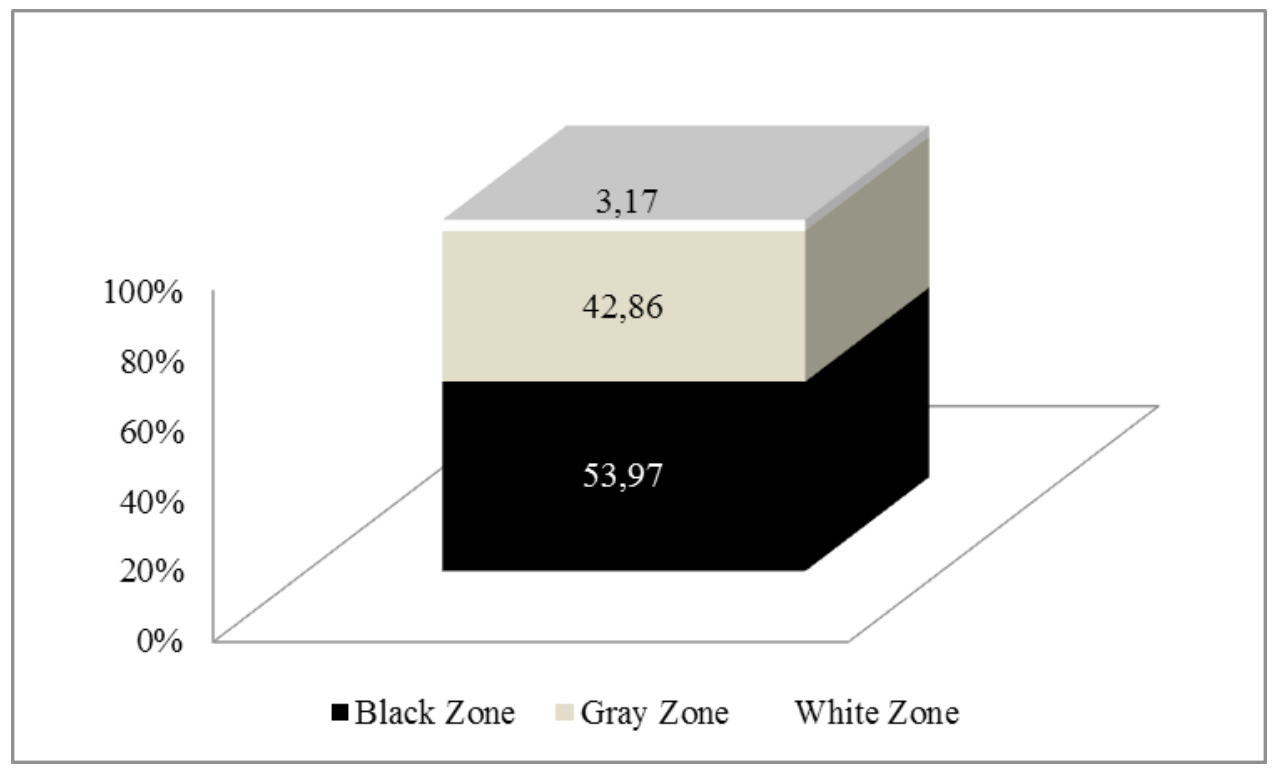

Source: Authors' calculation

The agricultural businesses suffer from a lack of capital and unfavourable loan conditions (Kocsis, Major, 2017). In order to effectively allocate limited funds intended for financing innovative activities, it is necessary to co-finance projects run by mediumsized agricultural enterprises operating in the white zone of business and for which the probability of bankruptcy is negligible. Medium-sized agricultural enterprises operating in the white zone of business are predominantly engaged in growing cereals (except rice), legumes and oil plants. Besides producing foods, small- and mediumsized enterprises (SMEs) play an important role in food processing and retail — and thus in the overall food value chain (Demmler, 2020).

The $\mathrm{Z}$ score indicate the financial position of the companies in the analyzed period and whether it is repaired or worsened (Vukadinović, Vujovič \& Vojnović, 2108). In addition to the $\mathrm{Z}$ score, a precise co-financing decision requires a detailed analysis of each financial component (indicator) of the model. Accordingly, a detailed analysis of the operations of medium-sized agricultural enterprises operating in the white zone shows that:

- all enterprises record a negative value of the X1 indicator. Although there is not a defined optimum value for the X1 indicator, those enterprises where this value is recoding a growing trend are positively evaluated. A negative value indicates the absence of financial stability and liquidity, while different positive values of this indicator indicate a lesser or greater degree of ability to settle due liabilities and expand operating operations. 
- all enterprises record unprofitable operations. X2 indicator with a value of zero or less than zero $(\mathrm{X} 2 \leq 0)$ indicates unprofitable business operations and the absence of the possibility of enterprise's survival in extraordinary adverse circumstances.

- all enterprises are characterized by low financial strength and low asset productivity. A value of indicator $\mathrm{X} 3$ that is zero or below zero $(\mathrm{X} 3 \leq 0)$ indicates that enterprises are unable to make a profit from the total invested assets.

- $50 \%$ of medium-sized agricultural enterprises operating in the white zone are capable to maintain their own reproduction, i.e. they record the value of X4 indicator higher than zero. As they use their own sources of financing for reproduction purposes, these enterprises do not burden the gross financial result with financing costs (Đuričin, S., 2012). The value of the previous indicators leads to the assumption that $50 \%$ of enterprises can finance only simple reproduction. Simple reproduction funding implies the re-acquisition of fixed assets and inventories at unchanged physical level. In this way, the business operation is ensured in an unchanged physical volume, but it is not possible to increase business activity.

- $50 \%$ of medium-sized agricultural enterprises operating in the white zone record successful sales based on assets employed. The value of X5 indicator higher than zero $(X 5 \geq 0)$ indicates a progressive market share. Any enterprise with successful sales based on the assets employed has a stable market share but not great potential for its growth.

The research results indicate a small number of enterprises operating in the white zone out of the total number of medium-sized agricultural enterprises. A detailed analysis of the financial indicators of each individual enterprise in this group shows that operation in the white zone does not necessarily imply readiness for innovative activities. Enterprises operating in the white zone have greater potential for innovation development than those enterprises operating in the grey and black zones. The presence of potential for innovation development does not necessarily imply readiness to pursue innovative activities (Đuričin, Beraha, 2018b). Therefore, it is necessary to analyse the key financial indicators for each individual enterprise from the white zone. Only $50 \%$ of medium-sized agricultural enterprises operating in the white zone are capable to maintain their own reproduction and record growth in market share, while all enterprises are characterized by insufficient profitability, i.e. insufficient financial strength and stability.

The previous analysis results led to further research of the potential for the development of innovative activities in medium-sized enterprises operating in the processing industry. Medium-sized enterprises from the food processing industry were considered. A more detailed research aims to determine whether agriculture is more likely to develop innovative activities if it is in the function of the processing industry. Furthermore, it is thus possible to make a comparative analysis between the potential for the development of innovative 
activities in enterprises registered in agriculture and enterprises registered in the food processing industry. The food industry determines not only the export but also the food security of the country, and it provides the production of raw materials for other industries and has a manifold influence and importance for complementary agricultural development and intensification of production in it (Milanovi et al., 2016; Mićić, Zeremski, 2011).

Using the Altman $\mathrm{Z}$ score method, the following results were obtained about the financial failure of medium-sized enterprises in the food processing industry:

- $14.06 \%$ in black zone,

- $43.75 \%$ in grey zone, and

- $42.19 \%$ in white zone.

Figure 2. Results of the Altman $\mathrm{Z}$ score model in medium-sized food processing enterprises - in \% -

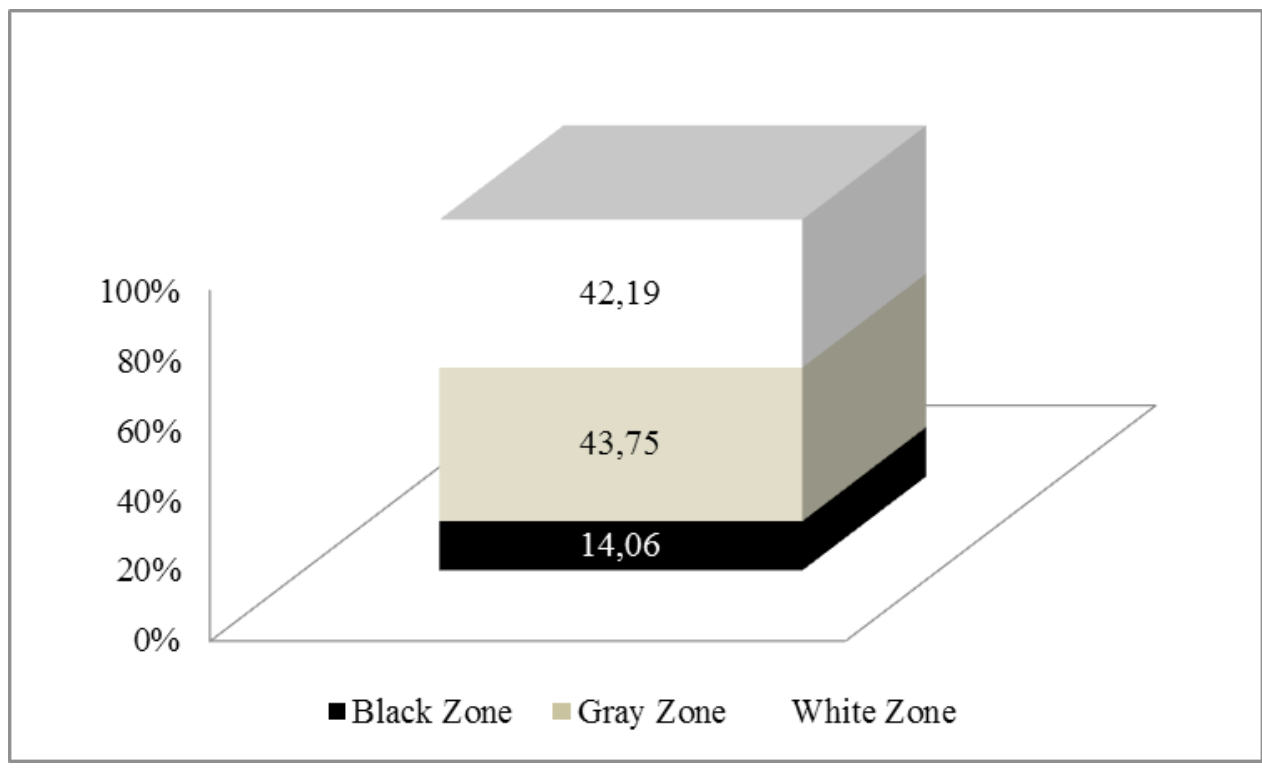

Source: Authors' calculation

A detailed analysis of each financial component of the $\mathrm{Z}$ score model in medium-sized enterprises operating in the white zone within the food processing industry shows:

- 74\% of enterprises record a positive value of X1 indicator. The determined value of this indicator points to the fact that $74 \%$ of the enterprises operating in the white zone are characterized by liquid business, i.e. business operation with financial stability and the ability to expand its operating business.

- $33 \%$ of enterprises record a positive value of X2 indicator, which indicates their profitable business and the possibility of surviving in extraordinary adverse circumstances. 
- given the value of X3 indicator, all enterprises are characterized by low productivity of assets.

- all medium-sized food processing enterprises operating in the white zone are capable to maintain their own reproduction, i.e. they record a value of X4 indicator that is higher than zero. Among these enterprises, 22\% are capable to perform their own simple reproduction and $78 \%$ the expanded own reproduction. Enterprises that are capable to perform extended reproduction from their own resources can maintain fixed assets and fixed stock at an unchanged physical level, but also acquire new fixed assets and fixed stocks that affect the increase in the physical volume of business (Đuričin, 2018).

- $78 \%$ of medium-sized agricultural enterprises operating in the white zone record successful sales based on assets employed. These enterprises have a value of $\mathrm{X} 5$ indicator higher than one $(\mathrm{X} 5 \geq 1)$ indicating a progressive market share.

A comparative analysis of the results obtained using the Altman $Z$ score method indicates a significantly larger number of food processing enterprises operating in the white zone. Population growth, technology development and differentiation of taste preferences expand the importance and role of food industry in the contemporary society (Topleva, Prokopov, 2020). Compared to medium-sized agricultural enterprises, medium-sized enterprises operating in the food processing industry have greater financial stability, asset liquidity and productivity, more profitable operations and more progressive market share. This means that agribusinesses are able to generate more sales by using their assets more efficiently in the food processing sector as compared to other sectors of the economy (Katchova, Enlow, 2013). Consequently, the potential for the development of innovative activities in the field of agriculture can be realized through more intensive cooperation with enterprises in the field of food processing industry. Ratings of the most potential sectors were analysed for more precise targeting of the branches of agricultural activity that have the greatest potential for developing cooperation with the food processing industry. The most potential sectors within the food processing industry with which cooperation needs to be established were observed according to the value of the Altman $\mathrm{Z}$ score model indicators. The analysis provided the following results:

- In terms of the potential for growth of market share and the ability to perform own extended reproduction, the greatest potential is recorded in medium-sized enterprises registered for:

- 1061: Manufacture of grain mill products, and

- 1091: Manufacture of prepared feeds for farm animals.

- In terms of asset productivity, the greatest potential is recorded in mediumsized enterprises registered for: 
- 1091: Manufacture of prepared feeds for farm animals,

- 1032: Manufacture of fruit and vegetable juice, and

- 1051: Operation of dairies and cheese making.

- In terms of profitability and the possibility to survive in extraordinary adverse circumstances, the greatest potential is recorded in medium-sized enterprises registered for:

- 1091: Manufacture of prepared feeds for farm animals,

- 1011: Processing and preserving of meat,

- 1061: Manufacture of grain mill products, and

- 1051: Operation of dairies and cheese making.

- In terms of liquidity and financial stability, the greatest potential is recorded in medium-sized enterprises registered for:

- 1061: Manufacture of grain mill products

- 1091: Manufacture of prepared feeds for farm animals

- 1032: Manufacture of fruit and vegetable juice

- 1051: Operation of dairies and cheese making

- 1039: Other processing and preserving of fruit and vegetables

- 1011: Processing and preserving of meat

- 1107: Manufacture of soft drinks, production of mineral waters and other bottled waters

At the modern stage of development of economy, development and implementation of breakthrough innovations in food industry in concentrated in the production sphere of activities of large food associations that have a structure of holding or concern, with a reserve of financial sustainability, sufficient volume of investment resources, and availability of necessary preconditions for formation of synergetic effect (Sibirskaya et al., 2017). Food industry innovation strategies need to be based on the total technology in the food system and concerned not only with the technological changes but also with the social and environmental changes, so as to produce food that satisfies the nutritional, personal and social needs and wants of all communities (Earle, 1997).

Opportunities for indirect development of innovative activities in the agricultural sector in cooperation with the food processing industry are growing in proportion to improving the cooperation between science and industry (Beraha, 2019). The university business cooperation includes many elements from human resources involved (academic staff, students, company employees), to intellectual property rights, legal aspects in contracts, funding start-ups and spin-offs to communication and promotion of the relationship and 
common projects (Dan, 2013). To realize these goals, initiatives to strengthen existing knowledge flows between universities and firms must be developed, and policies to encourage new university-industry linkages must be implemented (Bramwell et al., 2012). Therefore, the largest percentage of co-financed projects is in the field of food and agriculture within the Collaborative Grant Scheme Program implemented by the Innovation Fund. The co-financing effects of these projects were evaluated in the study "Quantitative Analysis of the Impact of Innovation Policy and Industry 4.0 on Development of Economy, Technological Progress and Entrepreneurship in Serbia". The study was conducted by the Institute of Economic Sciences for the needs of the Cabinet of Minister without portfolio responsible for innovation and technological development. The research was conducted in 2018 and was funded by HELVETAS Swiss Intercooperation SRB as part of the PERFORM project.

According to the research results of the PERFORM project, the co-financing effects of innovative activities under the three programs are different. Within the Collaborative Grant Scheme Program, the co-financing effects of innovative activities are as follows:

- Out of 14 projects funded, 30\% are from the food and agriculture sectors,

- Goals of participating in the Program are multiple but most beneficiaries wanted to develop a new product/service,

- The biggest obstacles beneficiaries face when implementing innovative/R\&D activities are costs/finance, technical challenges and equipment/research infrastructure,

- Given the implementation of projects, all beneficiaries improved technical/R\&D activities, $85.7 \%$ of them improved technical knowledge/understanding, $60 \%$ of beneficiaries increased availability of equipment/research infrastructure, $60 \%$ of beneficiaries improved cooperation and knowledge transfer, and $43 \%$ of them improved innovative culture and innovative capacities;

- The most significant direct effect of project implementation so far on the business performance of beneficiaries is the increase in the number of beneficiaries' employees $(85.7 \%)$, while beneficiaries' sales and export revenues increased by $28.6 \%$,

- Without the financial support of the Fund, $27 \%$ of projects would probably be realized, $43 \%$ might be realized, $15 \%$ would probably not be realized, and $15 \%$ would certainly not be realized,

- Thanks to participation in the Program, $86 \%$ of beneficiaries improved their image/reputation to some extent,

- The most pronounced impact on society is exerted by projects in the field of access to information and technologies and environmental protection, and to a lesser extent by projects in the fields of education, agriculture and food technology and communication, etc. 
Besides considering the effects arising from projects implemented under the Collaborative Grant Scheme Program, it is also necessary to consider the awareness of the need to develop innovative activities and the cooperation between economy and scientific and research organizations. According to the research results of the PERFORM project:

- $6 \%$ of SMEs and entrepreneurs (SMEEs) are fully familiar and 23\% of SMEEs are not at all familiar with current national regulations governing innovation,

- $30 \%$ of SMEEs are fully familiar and 3\% of SMEs are not at all familiar with the concept of innovation,

- $9.7 \%$ of SMEEs are fully aware and $29 \%$ are not familiar with the services of organizations providing infrastructure support for innovation,

- Strategic documents and/or business plans define goals for innovative development in $67.74 \%$ of SMEEs, i.e. they do not exist in $32.3 \%$ of SMEEs,

- As the most represented innovative activity in their enterprise, $54.8 \%$ of SMEEs consider the procurement of machines, equipment and software made for the purpose of innovation development,

- In the SMEEs innovation, which occur as a result of innovative activities, product/service innovation accounts for $45 \%$, process innovation $25 \%$, organization innovation $17 \%$, and marketing innovation $13 \%$.

- $25 \%$ of institutes and faculties cooperate with large enterprises and SMEE sector, while $75 \%$ of them have not developed this type of cooperation,

- $50 \%$ of institutes and faculties rate the application of scientific knowledge in practice as decent, $25 \%$ of them rate it as good, and $25 \%$ as poor,

- $62.5 \%$ of institutes and faculties believe that the level of technology transfer to the economy is decent. $12.5 \%$ of them assess the level of technology transfer to the economy as good and $25 \%$ as poor,

- Out of the total number of institutes and faculties that use funds from the budget of the Republic of Serbia, $62.5 \%$ of them use funds for research and development, and $25 \%$ for financing innovative activities, etc.

\section{Conclusion}

A small number of medium-sized agricultural enterprises operate in the white zone of business. Enterprises operating in the white zone have greater potential for innovation development, but this potential does not necessarily imply the willingness to pursue innovative activities. Only $50 \%$ of medium-sized agricultural enterprises operating in the white zone are capable to maintain their own reproduction and record growth in market share, while all enterprises are characterized by insufficient profitability, i.e. insufficient financial strength and stability. 
Weak economic and financial strength of medium-sized agricultural enterprises has influenced the deepening of research and examining the possibility of developing innovative activities through cooperation with food companies. The results of further research show that medium-sized enterprises in the food industry have much greater potential to develop innovative activities. Compared to medium-sized agricultural enterprises, medium-sized enterprises operating in the food processing industry report better asset productivity and greater liquidity. Furthermore, these companies are characterized by financial stability, progressive market share and profitable operations.

The branch of agriculture with the greatest prospect of developing innovative activities is the one providing raw materials for the food processing industry under code 1091: Manufacture of prepared feeds for farm animals. Furthermore, the perspective for development is exercised by the agricultural branches that deal with the following activities of the food industry: 1061: Manufacture of grain mill products, 1032: Manufacture of fruit and vegetable juice, 1051: Operation of dairies and cheese making, 1011: Processing and preserving of meat, 1039: Other processing and preserving of fruit and vegetables, and 1107: Manufacture of soft drinks, production of mineral waters and other bottled waters.

The development of innovation activities in agriculture in cooperation with the food processing industry is possible through the intensification of cooperation between science and economy. The effects of realized projects under the Collaborative Grant Scheme Program, funded by the Innovation Fund, were examined in order to improve the cooperation between science and economy. Observing the effects of the implemented projects within the Collaborative Grant Scheme Program, was aimed at indicating the current situation, and therefore the elements of cooperation that need to be intensified and improved. Research findings show that the biggest barriers facing Program beneficiaries are related to costs/finance, technical challenges and equipment/research infrastructure. In addition to the mentioned barriers that the Program beneficiaries encountered during the implementation of the projects, the most significant results of cooperation between science and economy were identified. Thanks to the realization of the projects, all beneficiaries improved technical/R\&D activities. Approximately $86 \%$ of beneficiaries upgraded technical knowledge and $60 \%$ of them increased the availability of research infrastructure and improved collaboration and knowledge transfer. Improvement of innovative culture and innovative capacities was observed in $43 \%$ of beneficiaries of the Collaborative Grant Scheme Program.

To remove the barriers that exist in the implementation of projects under the Collaborative Grant Scheme Program, the results of the intensity of innovative activities of the SMEE sector and scientific research organizations were presented in the research. These results represent only part of the PERFORM project and indicate, among other things, that only $6 \%$ of SMEEs are fully aware of current national regulations governing innovation. In addition, 9.7\% of SMEEs are fully aware and $29 \%$ of SMEEs are not at all familiar with the organizations' services of infrastructure support for innovation. Furthermore, $25 \%$ of institutes and faculties developed cooperation with large enterprises and SMEE 
sector, while $75 \%$ of them did not develop this type of cooperation. $62.5 \%$ of institutes and faculties believe that the level of technology transfer to the economy is decent. $12.5 \%$ of them assess the level of technology transfer to the economy as good and $25 \%$ as poor. Out of the total number of institutes and faculties that use funds from the budget of the Republic of Serbia, $62.5 \%$ of them use funds for research and development, and $25 \%$ for financing innovative activities, etc.

The research results indicate that the potential for the development of innovative activities in medium-sized agricultural enterprises can be improved through cooperation with food processing companies, primarily through strengthening the cooperation between science and economy and more intensive transfer of technological solutions to the economy. Furthermore, for the above conclusions, information was presented that could encourage future research aimed at enhancing the cooperation between science and economy, especially in the field of food industry and agriculture. In this way, a more efficient placement of funds intended for financing innovative activities will be ensured in the future.

\section{Acknowledgements}

This paper is a result of research financed by the Ministry of Education, Science and Technological Development of the Republic of Serbia. Also, this research is supported by PERFORM project of Swiss Agency for Development and Cooperation (SDC), implemented by HELVETAS Swiss Inter-cooperation and University of Fribourg. The views set out in this research are those of the authors and do not necessarily reflect the opinion and views of the Swiss Agency for Development and Cooperation nor the HELVETAS Swiss Intercooperation and the University of Fribourg.

\section{Conflict of interests}

The authors declare no conflict of interest.

\section{References}

1. Altman, E.I. (1968). Financial Ratios, Discriminant Analysis and the Prediction of Corporate Bankruptcy. The Journal of Finance, 23(4), 589-609. https://doi. org/10.2307/2978933

2. Altman, E.I. (2000). Predicting Financial Distress of Companies: Revisiting the Z-Score and Zeta Models, Stern School of Business, Paper is adapted and updated from E. Altman, Financial Ratios, Discriminant Analysis and the Prediction of Corporate Bankruptcy, Journal of Finance, September 1968; and E. Altman, R. Haldeman and P. Narayanan. 1997. Zeta Analysis: A New Model to Identify Bankruptcy Risk of Corporations, Journal of Banking \& Finance, 23(4), 589-609. https://doi.org/10.4337/9780857936097.00027

3. Beraha, I. (2019) Ocena inovativnih performansi Republike Srbije. Ekonomski vidici, 24(3-4), 137-151. 
4. Bramwell, A., Hepburn, N., \& Wolfe, D.A. (2012). Growing Innovation Ecosystems: University-Industry Knowledge Transfer and Regional Economic Development in Canada, Knowledge Synthesis Paper on Leveraging Investments in HERD Final Report to the Social Sciences and Humanities Research Council of Canada.

5. Dan, M.C. (2013) Why Should University and Business Cooperate? A Discussion of Advantages and Disadvantages. International Journal of Economic Practices and Theories, 3(1), 67-74.

6. Demmler, K.M. (2020). The role of small and mediumsized enterprises in nutritious food supply chains in Africa, GAIN Working Paper Series $\mathrm{n}^{\circ} 2$, Retrieved from: https://www.gainhealth.org/sites/default/files/publications/documents/gainworking-paper-series-2-the-role-of-small-and-medium-sized-enterprises-innutritious-food-supply-chains-in-africa.pdf (December 20, 2020).

7. Đuričin, S. \& Beraha, I. (2018a). Financial power and development potential of environmentally responsible medium sized enterprises in the Serbian industrial sector, Sustainable growth and development in small open economies, Budapest: Institute of World Economics; Centre for Economic and Regional Studies of the Hungarian Academy of Sciences, 124-142.

8. Đuričin, S. \& Beraha, I. (2018b). Promoting the Intensity of Innovative Activities of SMEs in the Republic of Serbia, Western Balkans Economies in EU Integration: past, present and future, CEMAFI International Association, 188-201.

9. Đuričin, S. (2012). Analiza poslovanja i mogućnosti izlaska preduzeća iz zone gubitka. Institute of economic sciences, Belgrade.

10. Đuričin, S. (2018). Improving the Efficient Use of the Government Budget Allocations for Financing Innovation Activities, Digital transformation: new challenges and business opportunities, London: Silver and Smith Publishers, 311-328.

11. Đuričin, S. (2019). Strategijsko \& finansijsko upravljanje organizacionim performansama. Institute of economic sciences, Belgrade.

12. Đuričin, S., \& Bodroža, D. (2013). The impact of drought on yield position of the group of enterprises from agriculture sector, Economics of agriculture, 60(1), 25 39.

13. Đuričin, S., Beraha, I., \& Bodroža, D. (2018). Alternatives for Exiting the Loss Zone for Mediumsized Agricultural Enterprises in the Republic of Serbia. Economics of agriculture, 65(1), 391-411. https://doi.org/10.5937/ekoPolj1801391D

14. Earle, M.D. (1997). Innovation in the food industry. Trends in Food Science \& Technology, 8(5), 166-175. https://doi.org/10.1016/S0924-2244(97)01026-1

15. Elena, V., Sibirskaya, E.V., Lyapina, I.R., Vlasova, M.A., Petrukhina, E.P. \& Timofeeva, S.A. (2017). Synergetic Effectiveness of Investing the Innovative Activities in Russian Food Industry, Russia and the European Union, 245-251.

16. Eurostat, Retrieved from http://ec.europa.eu/eurostat/web/science-technology -innovation/data/main-tables (July 20, 2018). 
17. Institut ekonomskih nauka (2018). Kvantitativna analiza uticaja inovacione politike i industrije 4.0 na razvoj ekonomije, tehnološkog napretka i preduzetništva u Srbiji, PERFORM projekat, HELVETAS Swiss Intercorporation SRB.

18. Katchova, A.L., \& Enlow, S.J. (2013). Financial performance of publicly \& traded agribusinesses. Agricultural Finance Review, 73(1), 58-73.

19. Kocsis, J., \& Major, K. (2017). A General Overview of Agriculture and Profitability in Agricultural Enterprises in Central Europe, Managing Agricultural Enterprises, Part IV, 243-265.

20. Mićić, V. \& Zeremski, A. (2011). Deindustrijalizacija i reindustrijalizacija privrede Srbije. Industrija, 39(2), 51-68.

21. Milanović, M.R., Stevanović, S. \& Dimitrijević, B. (2016). Agrarian potentials in the reindustrialization of Serbia - import of inputs and the opportunity costs of development. Economics of agriculture, 63(1), 143-158. https://doi.org/10.5937/ ekoPolj1601143M

22. Ministry of Education, Science and Technological Development (MESTD). Retrieved from http://www.mpn.gov.rs/tehnoloski-razvoj-2/inovaciona-delatnost/ registar-inovacione-delatnosti/ (March 15, 2018).

23. Rajin, D., Milenković, D., \& Radojević, T. (2016). Bankruptcy prediction models in the Serbian agricultural sector. Economics of agriculture, 63(1), 89-105. https:// doi.org/10.5937/ekoPolj1601089R

24. Statistical Office of the Republic of Serbia (SORS), Statistical yearbook (2017). Retrieved from http://pod2.stat.gov.rs/ObjavljenePublikacije/G2017/pdf/ G20172022.pdf (July 12, 2018).

25. Topleva, S.A., \& Prokopov, T.V. (2020). Integrated business model for sustainability of small and medium-sized enterprises in the food industry: Creating value added through ecodesign. British Food Journal, 122(5), 1463-1483. https://doi. org/10.1108/BFJ-03-2019-0208

26. Vukadinović, P., Vujović, S., \& Vojnović, B. (2018). Analysis of the financial position of enterprises in privatization in the agricultural sector in Serbia. Economics of agriculture, 65(3), 955-970. https://doi.org/10.5937/ekoPolj1803955V 